\title{
Impact of the Multinational Development New Trends on International
}

\section{Capital Flows}

\author{
Weihui Feng ${ }^{1}$ \\ ${ }^{1}$ Shandong Yingcai University, Shandong, Jinan, 250104
}

\section{KEYWORDS: Multinational, Development New Trends, International Capital Flows}

\begin{abstract}
TNCs are both an important force in today's world economic development, but also an important driving force of economic globalization. After the Cold War, when the world economic and political situation has undergone profound changes, the development of multinational companies showing a series of new trends. With the continuous improvement of the status and development of transnational corporations, international capital flows very active. On the one hand, countries are expected to international capital flows big boy; the other hand, the Asian financial crisis, it also allows countries to feel wary. Today's international capital flows in terms of size, speed or form has new features that exhibit new trends in the capital under the profit-driven nature and it also has its inevitability.
\end{abstract}

\section{Introduction}

Multinational company is also known as multi-national companies, international companies, global corporations and multinational corporations. In 1974, the United Nations Economic and Social Council to adopt a unified / TNC 0 this resolution name. The simplest definition is that multinationals across borders, doing business in a foreign organization. It is the capital of enterprises by output, set up branches or control local enterprises to become its subsidiaries in two or more countries (regions), engaged in the production and international business activities of enterprises in a unified decision-making system parent company.

TNCs produce can be traced back 16th and 17th centuries. British East India Company was established in 1600 as a tool of colonial aggression and expansion, already has a prototype of multinational companies. Late 19th and early 20th century, and a true multinational organization with modern forms of industrial monopolies. At that time, in the economically more developed countries in Europe and the United States, some large enterprises through foreign direct investment, set up overseas branches and subsidiaries, which are more representative of the company, there are three: in 1865, Germany's Bayer chemical Friedrich the company opened a manufacturing facility in the United states aniline Albany, New York; 1866, the Swedish company Nobel Alfred the \# in Hamburg, Germany, opened a dynamite factory; 1867, American Singer sewing machine company in the UK Glasgow has established a sewing machine assembly plant. These are generally considered to be an early multinationals.

Multinational corporations are accompanied by an international division of labor, international trade and the development of international investment and the gradual formation and development. International division of labor is the condition of the formation of transnational corporations; international trade is the basis for the formation of transnational corporations; international movement of capital and direct investment is an important means multinational formation. 


\section{The New Trend of Transnational Corporations}

Precursor multinational companies can be traced back to the 19th century 60--70 years, until the interwar period, the development of multinational companies is only gradual. After World War II, due to technological advances, reduce competition and liberalization wave of goods, services and factors of production between the international mobility barriers, expanding the scope of international specialization, multinational companies gained rapid development and become international economic activity of traders, investors, technical communicators and people movers. By creating the international division of labor within the enterprise, multinational companies worldwide will organize the production process, as the core organizers of contemporary international economic life. According to some data of the United Nations Conference on Trade and Development and Investment Company multinational Heart 1994 World Investment Report "and provide some of the latest data show that the recent multinational corporations and their direct investment showed the following trends.

The total number of multinationals like was geometrically increasing further rapid expansion of the scale of investment in the world economy is growing. The total number of multinationals in the world in 1983 is 11,000, with overseas subsidiaries 112 000. By 1993, more than 37,000 multinational corporations dominate subsidiaries 200000 (not including a large number of non-holding contact) active in the world economic stage. According to statistics, one-third of world trade is within the company's business, about $80 \%$ technology transfer fee payments occur at the same enterprise. 1991 overseas branches of multinational sales of \$ 4.8 trillion, more than the total world trade, 2.4 times in the early 1980s. During 1982 to 1992, sales of the world's top ranked 200 large multinational companies to expand from \$ 3 trillion to \$ 5.9 trillion, an increase of nearly double the proportion of total global GNP rose from $24.2 \%$ to $26.8 \%$.

The uneven development is intensifying, the balance of power changes in major multinationals in developed countries significantly; as the US economic recovery, foreign direct investment began to rise, the nation's largest investor and largest host country status restored. Since the 1980s, multinational corporations dominated the US situation changed significantly. MNCs have the 1993 level divided by country. Germany has leapt to the top, up to 7100, Japan, Sweden, respectively 3650 and 3550, United States ranked only fifth, less than 300. Name multinationals, the US multinationals decreased from 80-60, Japan grew from 35 to 54. On the other hand, the total amount of direct international investment in 1990 was \$ 231.5 billion, 91-year \$ 191.9 billion, \$ 171.1 billion for the 92 years, it began to rise in 1993 to reach \$ 195 billion, of which 92 to the US \$ 3.4 billion investment. 1993 also began to rise, US foreign direct investment reached \$ 50 billion, US direct investment inflows reached \$ 32 billion. Cross-investment occurs in developed countries because of economic and technical level of the developed countries is relatively similar or close to, consumption and production patterns were also similar market structure. Between them since the inner and external environment has identity both sides have a clear mutual-generation and in terms of technology-intensive. In addition, some newly industrialized countries and regions, such as South Korea and Taiwan has become a net investor, foreign investment in Taiwan in recent years, a slight downward trend, and concentrated in Southeast Asia, Vietnam, and Korea is growing year by year, its foreign investment in the manufacturing sector as the guide, to invest in our country, Shandong, Shanghai, Xiamen, and growing.

The increased investment in developing countries, but the region unevenly distributed. Since World War II, international direct investment is mainly concentrated in the large triangle between the United States and Japan, the proportion of developing countries to invest in 1990 dropped to $16 \%$ then the situation changed. In 1992, total direct investment inflows in developed countries are 
\$ 101 billion, down 16 percent from the previous year. Billion US dollars, up 19\% over the previous year, 1993 total FDI inflows to developing countries \$ 80 billion, double the 91-year, 40\% of the world total. From a regional distribution situation, investment in developing countries, more concentrated in more than 10 countries in East, South America, where China in 1993 to shed \$ 26 billion, second only to the United States, accounting for $13.3 \%$ of total international direct investment. Increased capital inflows to developing countries, on the one hand explain the pattern of world trade is changing, increasing the position of developing countries, especially those who are deepening reform, expanding opening up of China. But on the other hand how developing countries rightly, rational use of funds, make that really add value, but also pay attention to some of the negative effects caused by excessive due to attract foreign investment generated.

\section{The Impact of the Multinational Development New Trends on International Capital Flows}

With the integration of international developments, the world's largest international multinationals increasing degree, in today's new trade protection but also the rise of the environment, which is access to foreign markets and to enter new market of production factors and a lot of foreign investment . Governments around the world increasingly recognize that foreign direct investment has become an important means of enhancing their business competitiveness. Developed countries have already realized their FDI policy liberalization and developing countries have started the process of its FDI policy liberalization. In this regard, some Asian countries and Latin American countries are in a leading position. This trend will continue to develop. At the same time, governments around the world have also been fully aware of the effects of multinational investment in the promotion of economic development, but also actively adjust their policies in accordance with their specific circumstances, to foreign capital inflows through foreign direct investment attraction, at the same time, the use of attracting foreign direct investment to obtain foreign advanced technology, skills, management experience, broaden the channels into the international market, to better promote economic growth and development.

This multinational investment liberalization and facilitation of foreign direct investment into the overall development trend in the 1990s was particularly evident, the United Nations Conference on Trade and Development of Transnational Corporations and Investment Division of the data showed that: from 1991 to 1994, 373 national FDI laws and regulations change, there are 373 in the direction of liberalization development; bilateral investment agreements and further enrich the liberalization of foreign investment at the national level by 1995, and between countries It has concluded 900 such agreements, including "write concluded since 1990. Also in the bilateral investment agreements signed by the emergence of new trends in the B conclude an inter developing bilateral investment agreements of rapid development. This is more appropriate macro investment environment in the world, so that multinational companies in international business for more access to and use of the high ground, replaced by international trade and investment as an international economic integration is the most important mechanism.

Now, developing countries have emerged more and more multinationals. Last year, foreign direct investment in developing countries is about \$ 33 billion pursuant to the United Nations Conference on Trade and Development prepared headquartered in developing countries, a maximum of 5 . Although there are five companies of foreign economic activity accounted for more than\% early, but the developing countries as a whole, they are still well below the level of cross-border multinational companies in developed countries. In order to maintain its international competitiveness, TNCs from developing countries are increasingly becoming important foreign investors. "95 World Investment Report" that multinational companies based in developing 
countries, a large number of prospects for the expansion and development of its foreign direct investment is very optimistic. Therefore, a lot of today's multinational foreign investment has become a subject of international capital flows constitute the total size.

\section{TNCs are Still the Mainstay of International Direct Investment}

Currently, international direct investment is investment of foreign multinationals. Since the 1990s, cross-border mergers and acquisitions to become the main form of foreign direct investment. 1995 accounted for 73\% of global M \& A amount when the FDI flows in 1998 appeared 12,500 from acquisitions, mergers and acquisitions throughout the year more than \$ 1.6 trillion, accounting for 63.8\% of global transnational direct investment, mergers and acquisitions worldwide in 1999 ( including cross-border $\mathrm{M} \& \mathrm{a}$ ) amounted to $\$ 3.317$ trillion, a record number. However, the current cross-border $\mathrm{M} \& \mathrm{~A}$ is cooling, slowing down, suggesting that cross-border $\mathrm{M} \& \mathrm{~A}$ is entering a period of adjustment. According to data published by the relevant bodies, first quarter of 2001, global M \& A transactions fell 54\% for the fourth consecutive quarter of decline. 2002 first-quarter transactions amounted to $\$ 479.2$ billion, down from last year's \$ 1 trillion over the same period, the number of transactions also fell 33\%. After the integration of the most difficult business of mergers and acquisitions mainly cross-border $\mathrm{M}$ participants slowdown has begun into the post-merger, and the different countries, different institutions and cultural conflict complicated contradictions, the only effective solution to these issues, M \& A participants They may end up profiting, but the failure of some cross-border mergers and acquisitions also attracted more attention.

\section{Conclusion}

In the contemporary world economic development, multinational corporations are a major economic force can not be ignored. With the development of multinational companies, people are deepening their understanding of transnational corporations. In recent years, the rapid development of transnational corporations, so that national economic dependence on international trade and investment generally improved, mutual openness of international markets is also increasing, unified world market is accelerating the formation. This will enable multinational companies faced with the broader market capacity, prompting larger expand production and sales in order to fully achieve economies of scale.

\section{REFERENCE:}

[1] UNCTAD. World Investment Report1992: Transnational corporations as engines of growth

[R].Switzerland: United Nations Publication, 1992.

[2] UNCTAD. World Investment Report 2012: Towards a New Generation of Investment Policies[R].Switzerland: United Nations Publication, 2012.

[3] J.H.Dunning. International Production and the Multinational Enterprise [M].Allen and Unwin,1981.

[4] Verson, R. International and International Trade in the Product Cycle [J].Quarterly Journal of Economics, 1966 (5).

[5] National Science Board. Science and Engineering Indicators [M]. Arlington:National Science Foundation, 2012. 